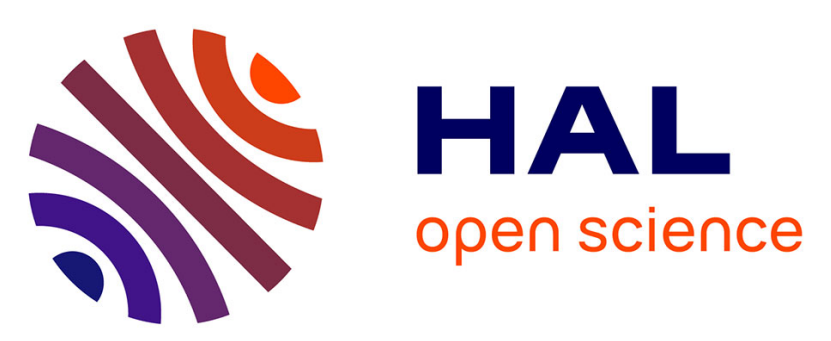

\title{
Contrasted taxonomic, phylogenetic and functional diversity patterns in semi-natural permanent grasslands along an altitudinal gradient
}

\author{
Rémi Perronne, Leslie Mauchamp, Arnaud Mouly, François Gillet
}

\section{- To cite this version:}

Rémi Perronne, Leslie Mauchamp, Arnaud Mouly, François Gillet. Contrasted taxonomic, phylogenetic and functional diversity patterns in semi-natural permanent grasslands along an altitudinal gradient. Plant Ecology and Evolution, 2014, 147 (2), pp.165 - 175. 10.5091/plecevo.2014.885. hal-01074588

\author{
HAL Id: hal-01074588 \\ https://hal.science/hal-01074588
}

Submitted on 14 Oct 2014

HAL is a multi-disciplinary open access archive for the deposit and dissemination of scientific research documents, whether they are published or not. The documents may come from teaching and research institutions in France or abroad, or from public or private research centers.
L'archive ouverte pluridisciplinaire HAL, est destinée au dépôt et à la diffusion de documents scientifiques de niveau recherche, publiés ou non, émanant des établissements d'enseignement et de recherche français ou étrangers, des laboratoires publics ou privés. 


\title{
Contrasted taxonomic, phylogenetic and functional diversity patterns in semi-natural permanent grasslands along an altitudinal gradient
}

\author{
Rémi Perronne, ${ }^{1,2, *}$, Leslie Mauchamp², Arnaud Mouly² \& François Gillet ${ }^{2,3}$
}

${ }^{1}$ INRA, UMR1347 Agroécologie, BP 86510, 17 rue de Sully, FR-21000 Dijon, France

${ }^{2}$ Université de Franche-Comté - CNRS, UMR 6249 Chrono-environnement, 16 route de Gray, FR-25030 Besançon Cedex, France

${ }^{3}$ Ecole Polytechnique Fédérale de Lausanne, Laboratory of Ecological Systems, Station 2, 1015 Lausanne, Switzerland

*Author for correspondence: remi.perronne@dijon.inra.fr

\begin{abstract}
Background and aims - Recent methodological and theoretical advances in community ecology have allowed more robust exploration of complementary facets of biodiversity in plant communities. Focusing on semi-natural permanent grasslands of the French Jura Mountains, we assessed how taxonomic, phylogenetic and functional diversity metrics vary among three phytosociological vegetation units.

Methods - We selected a sample of 135 relevés out of a phytosociological database, depicting three phytosociological orders (Brometalia erecti, Arrhenatheretalia elatioris and Trifolio repentis-Phleetalia pratensis) and including 381 vascular plant species. We built a phylogenetic tree based on sequences of two genes encoding chloroplast proteins, from which we computed phylogenetic diversity metrics that we compared to various taxonomic, single-trait and multi-trait functional metrics, including communityweighted means of functional traits (CWMs).

Key results - Most diversity metrics and CWMs significantly differed among vegetation units. Within each facet of biodiversity, the different metrics showed complementary results. Moreover, even when considering diversity metrics comparable in mathematical terms, i.e. based on Rao quadratic entropy, the results were largely non-redundant among the facets of biodiversity. Phylogenetic diversity and multi-trait functional diversity show opposite responses to vegetation units, as well as a low phylogenetic signal. These two results suggest that phylogenetic diversity cannot be used as a simple proxy for functional diversity.

Conclusion - This study highlights the importance of taking into consideration different facets for a better understanding of biodiversity. In particular, phylogenetic and functional facets appear highly informative, and could thus be used in addition to taxonomic diversity metrics as indicators of conservation value.
\end{abstract}

Key words - Diversity metrics, permanent grasslands, phylogenetic tree, Rao quadratic entropy, Jura Mountains.

\section{INTRODUCTION}

Beyond species richness, various diversity metrics have been proposed in community ecology, encompassing the different facets of biodiversity in species assemblages, i.e. taxonomic, functional, and phylogenetic (Devictor et al. 2010, Pavoine \& Bonsall 2011). In the meantime, technical facilities in ecology and evolution have progressed rapidly. This is especially the case in phylogenetics, where the availability of numerous genetic sequences, as well as the increase of computing power combined with new computation methods led to reconstruct detailed phylogenies for various families of plants. Recently, some studies have emphasized the interest of studying multiple facets of biodiversity (Devictor et al. 2010), including measures of phylogenetic structure and functional trait variation in communities across environmental gradients (Cianciaruso et al. 2012, Bernard-Verdier et al. 2013).

Despite these promising results arising from this new analytical framework, little is known about the complementarity of taxonomic, phylogenetic and functional facets of biodiversity at regional scale among vegetation units. Indeed, the study of functional and phylogenetic community structures has long aimed at understanding fine-scale community assembly. This is notably based on two main assumptions: (i) the traits are surrogates for individual performance (i.e. growth, reproduction and survival, Violle et al. 2007) and (ii) the phylogenetic structure can be considered as a surrogate of the functional structure of the community, according to 
the niche conservatism assumption (Harvey \& Pagel 1991). In contrast, the phytosociological approach is based on the comparison of plot records (i.e. species lists, called floristic relevés) to perform a hierarchical classification of plant community types (syntaxa, i.e. associations, alliances, orders and classes) at regional to continental scale (Braun-Blanquet 1964, Westhoff \& van der Maarel 1978). As a consequence, phytosociological classifications are widely used by conservation agencies as a basis to habitat classification and ecosystem health assessment.

Recently, the emergence of large phylogenetic, phytosociological and trait databases, coupled with the standardization of several computation methods, allows communitylevel studies combining different facets of biodiversity for numerous species, especially in order to compare vegetation units (Benson et al. 2006, Kleyer et al. 2008, de Bello et al. 2010, Dengler et al. 2011). Currently however, little is known about the phylogenetic and functional structures of phytosociological vegetation units, despite the recognized interest of using different aspects of biodiversity in conservation ecology (Stuart-Smith et al. 2013).

In the specific context of permanent semi-natural mountain grasslands, many botanical surveys have been conducted in Europe over the past decades to characterize vegetation units (Schaminée et al. 2009, Dengler et al. 2011). Regional phytosociological classifications of grasslands, although based on taxonomic criteria only, are mainly explained by environmental filtering (e.g. Ferrez et al. 2011). Particularly, agricultural management is assumed to play an important role in community assembly, and therefore phytosociological classifications, by inducing disturbances, such as grazing and mowing, as well as stress gradients (Ferrez 2007). In this context, phylogenetic and functional diversity metrics comparable in mathematical terms could prove useful to better understand anthropogenic impacts on grassland vegetation (e.g. de Bello et al. 2010). In order to develop a more comprehensive approach, they could be supplemented by the community-weighted means (CWMs) of plant functional traits (Ricotta \& Moretti 2011). Actually, some response functional traits are known to be related to anthropogenic disturbances in semi-natural grasslands (e.g. Kahmen \& Poschlod 2008).

Besides management-induced disturbances, many other factors such as climatic variations are known to influence the different facets of biodiversity in grassland communities. For instance in Western Europe, altitude is known to be strongly correlated with temperature and precipitation, which subsequently condition the phenological stages of plant species. However, few studies which have investigated the different facets of biodiversity in grasslands have taken into consideration this source of variation.

In this paper, we provide a case study based on phytosociological relevés sampled in semi-natural grasslands of the French Jura Mountains across an altitudinal gradient to address the following questions: (1) What is the influence of the altitudinal gradient on the patterns of diversity metrics and community-aggregated plant functional traits (CWMs)? (2) Is there any difference in taxonomic, functional and phy- logenetic alpha diversity metrics among the main phytosociological vegetation units?

\section{MATERIAL AND METHODS}

\section{Study area}

The study is based on phytosociological data collected in the French Jura Mountains. This region is characterized by an altitudinal gradient divided into three structural units: first plateau (500-800 $\mathrm{m}$ a.s.1.), second plateau (800-950 m a.s.1.) and high range (950-1700 m a.s.l.). Climate is nemoral with a strong suboceanic influence. Predominant soils are cambisols developed on limestone with a variable superficial cover of wind silt depositions. Permanent grasslands, either episodically or regularly mown and/or grazed, represent $22 \%$ of the area (Mauchamp et al. 2013).

\section{Data selection}

From the Taxa database (Ferrez 2007), provided by the CBNFC (Conservatoire Botanique National de FrancheComté), we extracted 2335 phytosociological relevés recorded in grasslands of the French Jura Mountains. We imported these relevés in Phytobase 8.1, a relational database devoted to vegetation analysis (Gillet 2010). For each floristic relevé, performed on approximately $100 \mathrm{~m}^{2}$, species abundancedominance codes (Braun-Blanquet 1964) were converted into relative percentage cover, summing to $100 \%$ for each plot (Gillet 2010).

We first selected the subset of relevés related to permanent grasslands of the Jura Mountains at an altitude between 500 and $1300 \mathrm{~m}$ a.s.l. We excluded relevés from uplands (subalpine belt) or wetlands. For each selected relevé, we then performed a diagnosis of phytosociological classes, orders and alliances according to Julve's classification (Julve 1993, 2013) and based on species fidelity indices (Gillet 2010). On this basis, we selected all relevés belonging to three phytosociological orders: Arrhenatheretalia elatioris (nutrient-rich hay meadows), Trifolio repentis-Phleetalia pratensis (nutrient-rich pastures) and Brometalia erecti (nutrient-poor limestone grasslands). These three orders include the most frequent semi-natural grasslands in the study area (Ferrez et al. 2011). In the last step, we applied a stratified subsampling to retain approximately fifteen relevés for each combination of altitudinal classes (i.e. first plateau, second plateau and high range) and phytosociological orders, i.e. Brometalia erecti (thereafter 'Brometalia' or 'Be'), Arrhenatheretalia elatioris (thereafter 'Arrhenatheretalia' or 'Ae') and Trifolio repentisPhleetalia pratensis (thereafter 'Trifolio-Phleetalia' or 'TP'). A minimum geographic distance was chosen between relevés to avoid as much as possible spatial autocorrelation. Finally, our selection resulted in a dataset of 135 relevés encompassing 381 plant species for the subsequent analyses.

\section{Phylogenetic tree}

The Angiosperm phylogenetic tree was built from a larger number of species, related to the three previously defined phytosociological orders, but observed on additional surveys in the study area. It is composed of 54 families, 207 
genera and 426 species, with significant differences in number of species per genus as well as genera per family (electronic appendix 1). The construction of the phylogenetic tree is based on sequences of two genes encoding chloroplast proteins $(r b c L$ and $m a t K)$. Their complementarity allows a good resolution of the tree for the selected species (Hilu et al. 2003). The sequences were obtained using the GenBank database (Benson et al. 2006). For species not yet or partially sequenced for the selected genetic markers, we replaced them by the closest available relative in the light of phylogenetic relationships revealed by the recent literature, including APG III classification (APG 2009). This represented 13\% of the $r b c L$ dataset and $19 \%$ for $m a t K$. All sequences were first automatically aligned using ClustalX 2.1 software and then manually using Se-Al 1.0al software for both markers (Larkin et al. 2007, Rambaut 1996). A combined analysis of these two datasets was then performed following the Bayesian MCMC (Monte Carlo Markov Chain) approach using BEAST 1.5.3 software (Drummond \& Rambaut 2007). The ambiguously aligned regions of the matK gene have been excluded $(11 \%$ of $1010 \mathrm{bp})$. MrModeltest 2 v. 2.0 software was used to choose the model of nucleotide substitution that best fits the data, following Akaike's information criterion (Nylander 2004). The selected model was the general time reversible model (GTR) with among-site substitution rate heterogeneity described by a gamma distribution (Yang 1994). Several family relationships were constrained according to the APG III phylogeny (APG 2009) in BEAST to calibrate the rates of molecular evolution of each lineage for Angiosperms clades (Bell et al. 2005). Finally, for branch length calculation an uncorrelated relaxed molecular clock was used, which takes into account evolution heterogeneity between lineages (Drummond et al. 2006).

\section{Functional traits}

The functional approach is based on a set of response traits known to be related to management-induced disturbances in grasslands. These traits involve leaf morphology, plant morphology and reproductive characteristics (table 1). The selected traits are known to be specifically related to mowing, grazing and fertilization impacts, these management regimes leading to major compositional and structural changes in grassland communities (Jacquemyn et al. 2003, BernhardtRömermann et al. 2011, Gaujour et al. 2012).

\section{Diversity metrics}

Among taxonomic alpha diversity metrics, species richness $\mathrm{N}_{0}$ and inverse Simpson species diversity $\mathrm{N}_{2}$ were computed, based on the Rényi general entropy and expressed as species number equivalent (Hill 1973).

For the phylogenetic and functional facets of biodiversity, the Rao quadratic entropy (thereafter 'Rao') with Jost's correction (2007) was used, thereby obtaining a synthetic diversity index directly comparable to $\mathrm{N}_{2}$ (de Bello et al. 2010). To compute Rao phylogenetic diversity, the ultrametric distance from the phylogenetic tree was considered. To compute Rao functional diversity, Euclidean distance for quantitative traits (i.e. FID, Height, SLA, LMDC and square-root transformed SM, to meet normality), Sokal-Michener binary dis-

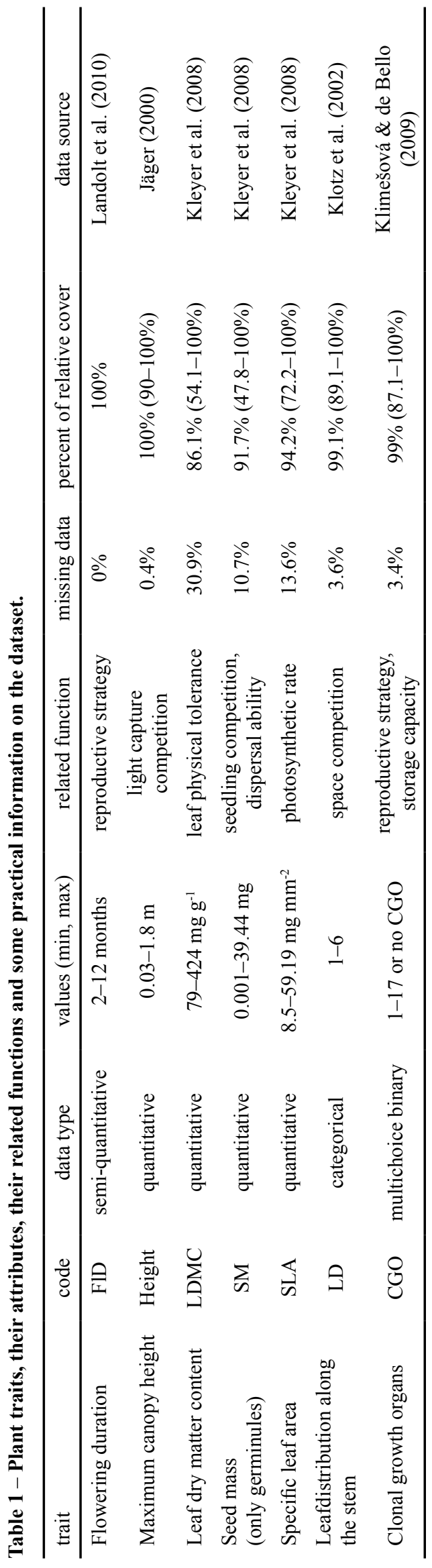


Table 2 - Phylogenetic signal for five functional traits based on Blomberg's K index.

The phylogenetic signal was first computed on the whole data set, then separately for monocot and dicot species. The number of species indicates the size of the species pool used to compute the phylogenetic signal for each trait. Bold font indicates significant phylogenetic signals $(\mathrm{P}<0.05)$.

\begin{tabular}{lcccc}
\hline trait & $\begin{array}{c}\text { number of species } \\
\text { (monocots / dicots) }\end{array}$ & all species & monocots & dicots \\
\hline Leaf dry matter content & $244(60 / 183)$ & 0.0077 & $\mathbf{0 . 0 2 8 8}$ & 0.0046 \\
Seed mass (only germinules) & $321(61 / 259)$ & 0.0007 & $\mathbf{0 . 0 2 9 9}$ & 0.0008 \\
Maximum canopy height & $360(77 / 282)$ & 0.0037 & 0.0065 & 0.0037 \\
Specific leaf area & $310(72 / 237)$ & 0.0029 & 0.0092 & 0.0026 \\
Flowering duration & $362(77 / 284)$ & 0.0014 & 0.0006 & 0.0025 \\
\hline
\end{tabular}

tance for nominal and multichoice nominal traits coded as dummy variables (i.e. LD and CGO, respectively), or Gower distance for the computation of multi-trait diversity metrics (see table 1 for details) were applied, respectively. In order to compare the mean trait values among plant communities, the CWMs (Garnier et al. 2004) were also computed.

For the single-trait functional facet of biodiversity, species with missing information were removed, so metrics were sometimes computed on less than $90 \%$ of the relative percentage cover (especially for LDMC and SM, see table 1 for details). Moreover, the abundance-weighted version of the metrics was always applied, because presence-absence data may miss ecologically interesting patterns. Finally, woody plants were ignored in functional analysis, considering their low relative cover (i.e. $0.2 \%$ on average) and because trait data at the seedling stage were generally unavailable.

\section{Phylogenetic signal testing}

Phylogenetic signal is primarily defined as the tendency of phylogenetically related species to resemble from each other, e.g. functionally, more than species drawn at random from the phylogenetic tree (Blomberg et al. 2003). Blomberg's K was used as a ranking index for trait phylogenetic signals (i.e. the higher the $\mathrm{K}$ values, the stronger the signal). The index expresses the strength of phylogenetic signal as the ratio of the mean squared error of the tip data measured from the phylogenetic corrected mean, and the mean squared error based on the variance-covariance matrix derived from the given phylogeny, assuming Brownian motion. In this way, $\mathrm{K}=1$ corresponds to trait evolution according to a Brownian motion evolution model. Following Bernard-Verdier et al. (2013), K values were compared to null distributions by shuffling species labels at the tip of the phylogeny 10000 times. The observed values in the upper fifth quantile of the null distribution were assumed significant. The number of species included in the phylogeny for testing phylogenetic signal varied depending on traits, ranging from 244 for leaf dry matter content to 362 for the flowering duration (table 2). The phylogenetic signal and functional trait conservation are not always uniform along the phylogenetic tree (Davies et al. 2013). Grasses are important components of grassland plant communities that structure habitats. Consequently, we proceeded to separate computations for monocot and dicot species as proxies for grasses and forbs, respectively, to test their own information and potential hidden signal.

\section{Data analysis}

Statistical analyses were performed using R 3.0.2 (R Development Core Team 2013), its packages 'ade4' (Chessel et al. 2013), 'FD' (Laliberté \& Shipley 2013), 'picante' (Kembel et al. 2013), 'phytools' (Revell 2013), 'phylotools' (Zhang et al. 2012) and 'vegan' (Oksanen et al. 2013), as well as specific $\mathrm{R}$ functions implemented by various authors including de Bello et al. (2010) and Borcard et al. (2011).

We tested Spearman rank correlation between each pair of quantitative traits. The spatial autocorrelation was tested among sites for each diversity metric using Moran's I statistic.

Variation in taxonomic composition among vegetation units was explored with a Principal Component Analysis (PCA) performed on Hellinger-transformed species data. Moreover, to express the main potential gradients of disturbances and fertilization in species composition, we projected on the PCA plot some relevant community-weighted mean ecological indicator values, using 'rda' and 'envfit' functions available in 'vegan' package. These indicator values are grazing tolerance, trampling tolerance, mowing tolerance from Biolflor database (Klotz et al. 2002), and the nutrient value, indicating the nitrogen and phosphorus content in the soil as a proxy of soil fertility and grassland productivity, from Flora Indicativa (Landolt et al. 2010).

To assess the relative importance of altitude and vegetation units on the metric values, we performed a partial redundancy analysis (pRDA) with diversity metrics as response variables, vegetation units as explanatory variable, and altitude as covariable (Borcard et al. 2011).

In addition, we tested Spearman rank correlation between altitude and metric values for each phytosociological order independently. The three vegetation units were compared, for each metric and indicator, with a non-parametric Kruskal-Wallis test associated with a post-hoc test for multiple comparisons. Given the number of pairwise comparisons, 
a sequential Bonferroni-Holm correction was applied to all multiple comparison tests (Holm 1979).

\section{RESULTS}

We found significant Spearman rank correlations between LMDC and SLA (rho $=-0.440$ ), SM and Height (rho = 0.334 ), and LDMC and Height ( rho $=-0.216$ ).

The spatial autocorrelation of the different diversity metrics was mostly non-significant. However, some metrics (6/16), especially including taxonomic (2/2) and phylogenetic $(1 / 1)$ metrics, were clustered across the region (electronic appendix 2A). This could partly be explained by the existence of the three altitudinal structural units on which the selection of relevés was made.

The PCA of Hellinger-transformed species cover data shows a clear segregation of relevés according to vegetation units (fig. 1). The first axis (18.6\% of the total variance) expresses a gradient of disturbance and soil fertility, opposing Arrhenatheretalia and Trifolio-Phleetalia to Brometalia, the latter showing low nutrient and mowing tolerance indicator values. The second axis $(7.9 \%)$ is more correlated with grazing and trampling tolerance, and thus allows distinguishing Arrhenatheretalia and Trifolio-Phleetalia.

\section{Relative influence of vegetation units and altitudinal gradient on metrics}

The partial RDA of diversity metrics constrained by vegetation unit and conditioned by altitude reveals that only $0.79 \%$ of the variance is explained by the altitude covariable, while the vegetation unit alone explains $23.20 \%$. In addition, when split by vegetation unit and after applying Bonferroni-Holm correction, Spearman tests only detect few significant correlations between diversity metrics and altitude (electronic appendix 2B). Thus, in our dataset, the altitudinal effect on diversity metrics is negligible compared to the differences among vegetation units.

\section{Comparison of diversity metrics among vegetation units}

Numerous metrics differed significantly among vegetation units, as evidenced by Kruskal-Wallis tests. Therefore, we used post-hoc tests to specify the response of taxonomic, functional and phylogenetic metrics (figs $2 \& 3$ ).

The two components of taxonomic diversity (i.e. species richness and evenness) seem to be partly complementary, and may differentiate phytosociological orders. The Brometalia have greater species richness $\mathrm{N}_{0}$, but show no difference in species diversity $\mathrm{N}_{2}$, compared to the Arrhenatheretalia and Trifolio-Phleetalia (fig. 2), due to a lower species evenness (data not shown).

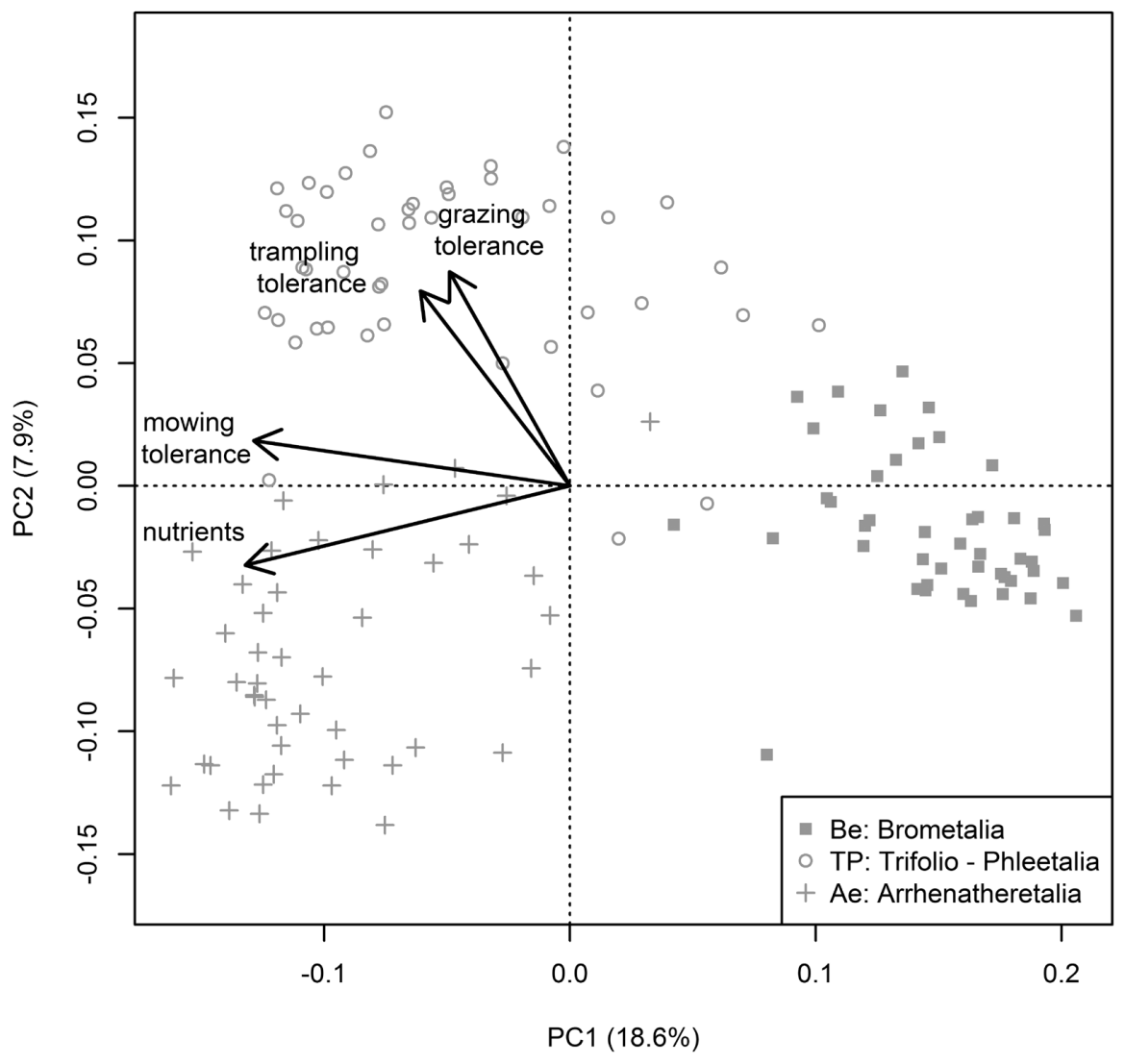

Figure 1 - PCA of the Hellinger-transformed species cover data of 135 grasslands of the Jura Mountains, and a posteriori projection of four ecological indicator values. 

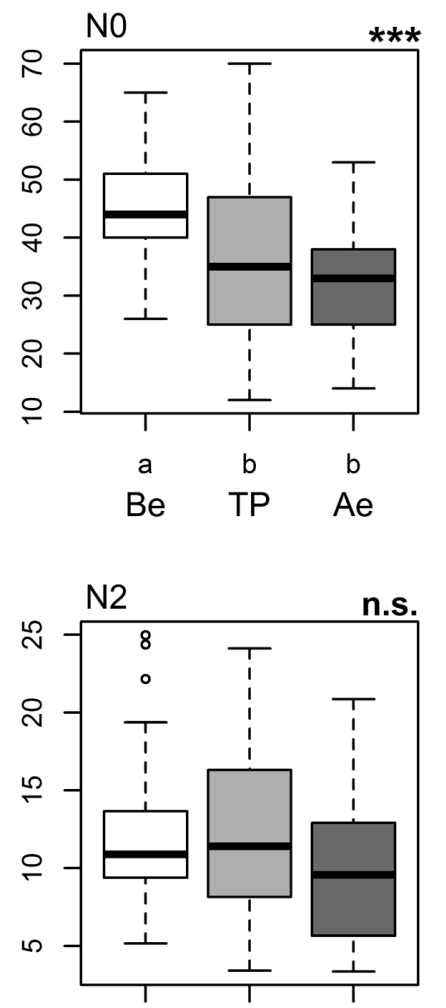

Be TP Ae vegetation unit
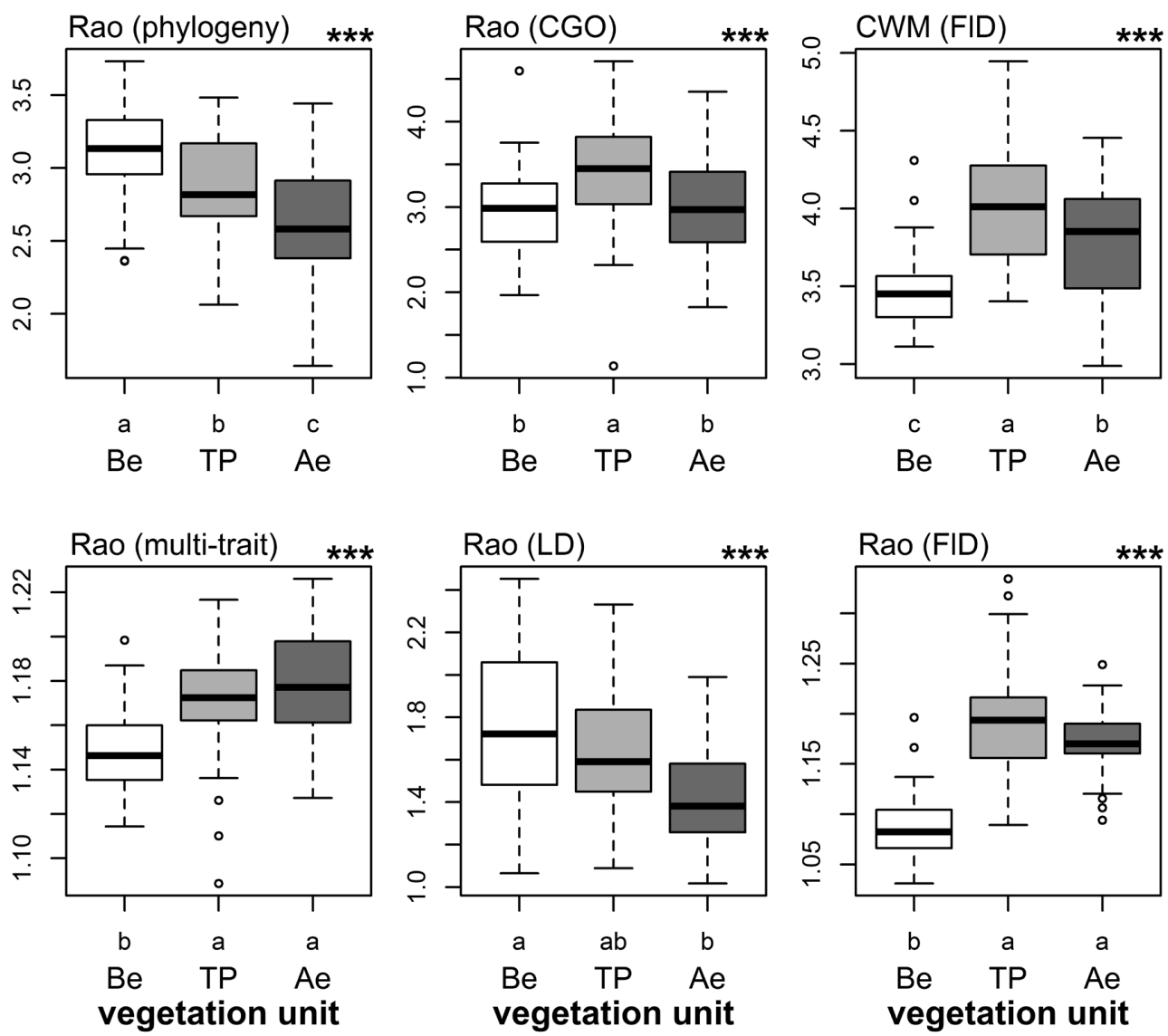

Figure 2 - Taxonomic, phylogenetic and functional metrics split by vegetation unit $(\mathrm{n}=135)$, with results of Kruskal-Wallis tests. $* \mathrm{P}<0.05, * * \mathrm{P}<0.01, * * * \mathrm{P}<0.001$, n.s. non significant. Letters indicate significant different values according to non-parametric post-hoc tests.

The Rao phylogenetic analysis mainly suggests that the Arrhenatheretalia communities are dominated by phylogenetically closer species than communities belonging to the other orders (fig. 2). In contrast, Brometalia show a more even distribution of dominant species along the phylogenetic tree.

The analysis of functional diversity using a set of response traits also shows numerous significant and complementary results. The Brometalia relevés are significantly more diverse than the Arrhenatheretalia (fig. 2) due to a substantial proportion of species with leaves distributed regularly along the stem, while rosette and semi-rosette species strongly dominate in the latter (electronic appendix 3A). Regarding clonal growth organs, the Trifolio-Phleetalia show more diverse communities with a more regular representation of the four main CGO forms (fig. 2 \& electronic appendix 3B). Some quantitative traits show highly distinct responses according to the computed metric while others exhibit common trends, regardless of the metric (e.g. respectively SLA and LDMC, fig. 3). Besides, several traits show similar trends, despite the non-significance of correlation among trait values.

The mean and diversity aspects of the panel of quantitative functional traits clearly differentiate the three vegetation units. The Brometalia relevés show on average heavier seeds and higher but more diverse LDMC than the Arrhenathereta- lia and Trifolio-Phleetalia relevés (fig. 3). The Arrhenatheretalia communities are characterized by taller species with higher SLA values, whereas the Trifolio-Phleetalia communities show a longer duration of flowering (figs $2 \& 3$ ). The functional diversity also presents distinct trends. Thus, the Brometalia appear less diverse than the Arrhenatheretalia regarding the flowering duration, while it does not show more diversity regarding SLA (fig. 2). Due to these differences among traits, the multi-trait Rao quadratic entropy index does not differentiate between Arrhenatheretalia and Trifolio-Phleetalia, both more variable than the Brometalia.

\section{Comparisons of diversity facets}

The significance of phylogenetic signal is quite low in all chosen traits, and the $\mathrm{K}$ values lower than expected under a Brownian motion model when considering all the species (table 2). Indeed, in general and for dicots, we observe a high trait variance within lineages $(\mathrm{K}<1)$. When considering monocots only, both the LDMC and the seed mass show a signal, albeit weakly significant (table 2), meaning that evolution of traits follows a Brownian motion.

Besides, there are several correlations among taxonomic, functional and phylogenetic abundance-weighted diversity metrics, both positive and negative (electronic appendix 4). For instance, the diversity of flowering duration is negatively 
correlated to the diversity of seed mass and LMDC, while positively to the canopy height (electronic appendix 4)

Finally, some metrics show opposite trends for different diversity facets among vegetation units (figs $2 \& 3$ ). As an example, the Rao quadratic entropy based on phylogeny shows clear opposite trends to the Height. In addition, the Rao quadratic entropy computed on multiple traits presents a distinct pattern compared to the phylogenetic metric, showing no significant correlation (fig. 2 \& electronic appendix 4).

\section{DISCUSSION}

\section{Negligible influence of the altitude on diversity metrics}

The altitude effect on diversity metrics seems negligible in this study, although we could not exclude the influence of a climatic gradient on the functional facets of biodiversity (Pellissier et al. 2010). However, in order to test this potential effect, it may need to perform field measurements, especially to capture the intraspecific variability. This variability seems otherwise more influenced by local conditions, such as management, than by climate (Pakeman 2013).
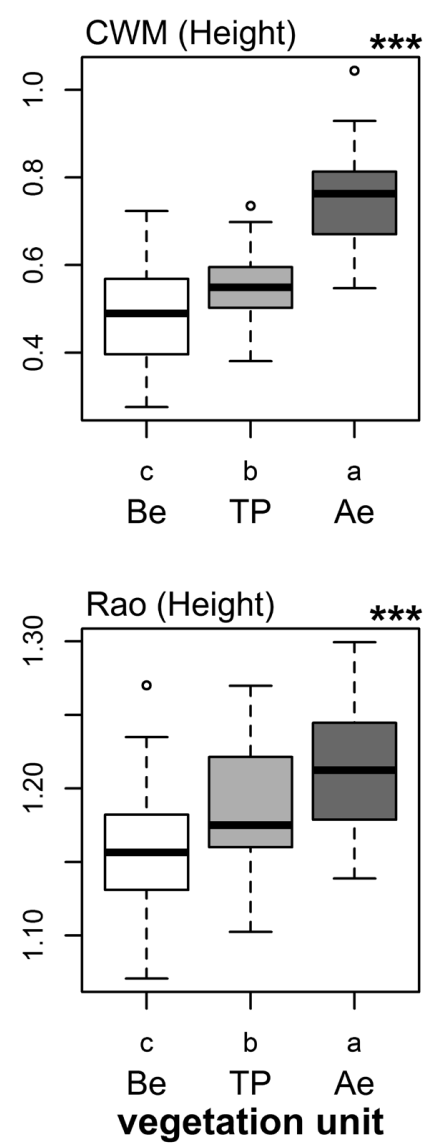

\section{Differences in taxonomic, functional and phylogenetic metrics among vegetation units}

The diversity metrics show many differences among phytosociological orders, both within and among facets of biodiversity.

Taxonomic metrics appear of some utility to underscore the differences between vegetation units. Whereas species richness is significantly lower in Arrhenatheretalia and Trifolio-Phleetalia, Simpson's diversity index $\mathrm{N}_{2}$ does not show any difference. In contrast, the lowest local species evenness (i.e. $\mathrm{N}_{2} / \mathrm{N}_{0}$, Gillet et al. 1999) is found in Brometalia relevés. This set of taxonomic differences could potentially be explained by a higher number of rare species per community in oligotrophilous semi-natural grasslands, otherwise known to be remarkably species-rich at fine spatial scale (Wilson et al. 2012, Mauchamp et al. 2013).

Using phylogenetic data, the Rao metric highlights highly distinct responses among vegetation units. The dominance of closely related species in the Arrhenatheretalia order may be explained by $54.7 \%$ of relative cover of Poaceae compared to $39.1 \%$ and $35.8 \%$ in Trifolio-Phleetalia and Brometalia, respectively. Besides, in the Trifolio-Phleetalia, the phylogenetic diversity is higher than in Arrhenatheretalia, despite comparable species richness and dominance, meaning that species are more evenly distributed along the phylogenetic tree, thus representing more lineages.
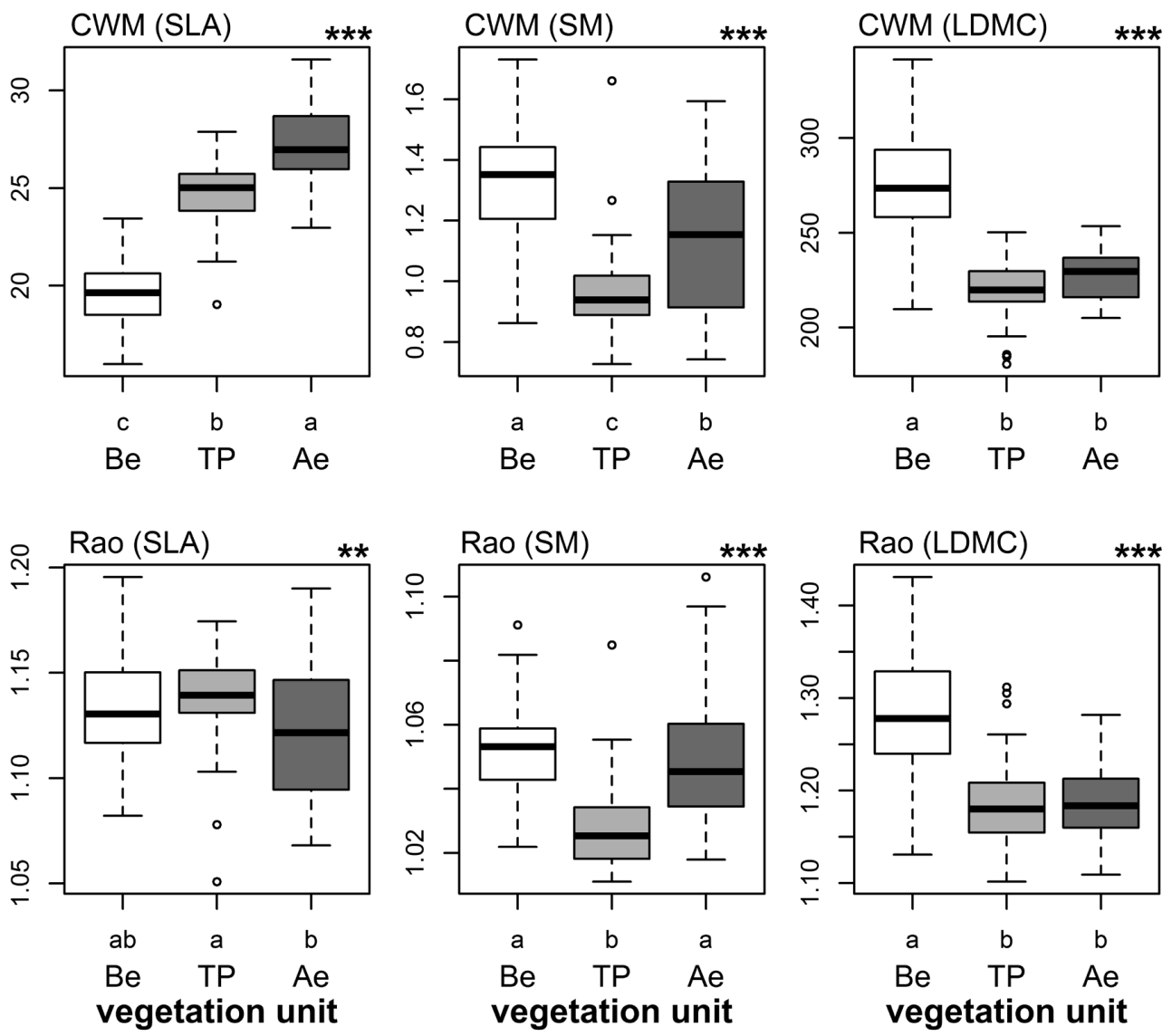

Figure 3 - Four quantitative functional metrics split by vegetation unit $(\mathrm{n}=135)$, with results of Kruskal-Wallis tests. $* \mathrm{P}<0.05, * * \mathrm{P}<0.01$, $* * * \mathrm{P}<0.001$, n.s. non significant. Letters indicate significant different values according to non-parametric post-hoc tests. 
Functional metrics may capture the complex structure of a community, thus providing potential interpretations of the underlying processes acting on disturbed plant communities (Mouillot et al. 2013). The chosen traits, although showing sometimes correlations, seem to adequately differentiate the three phytosociological units, revealing their complementarity. The Brometalia are characterized by communities with shorter flowering period, dominated by species with a lower canopy height, but producing heavier seeds and characterized by a higher LDMC. In contrast, the communities of the Arrhenatheretalia and Trifolio-Phleetalia orders are characterized by taller species with a higher SLA and a broader, though more variable flowering period. Finally, within the same phytosociological class, i.e. the Agrostio stoloniferaeArrhenatheretea elatioris, the Trifolio-Phleetalia differ from the Arrhenatheretalia by smaller species with lighter seeds and lower SLA.

\section{Complementary responses of biodiversity facets}

Our study shows the relative limitations of taxonomic diversity metrics used alone, and underlines the importance of taking into account the different facets of biodiversity.

The results of taxonomic metrics are consistent with Wilsey \& Polley (2003) that demonstrated an opposite pattern of species richness and evenness, emphasizing the limitations of an approach in which species richness is the only surrogate of biodiversity.

The functional diversity highlights several complementary responses among vegetation units, which mainly depend on the chosen trait. These single-trait responses could partly explain the absence of significant differences between $\mathrm{Ar}$ rhenatheretalia and Trifolio-Phleetalia when considering the multi-trait approach. This suggests the need to use a set of trait $\times$ metric combinations before any interpretation of community structure of semi-natural grasslands, given that several mechanisms can operate simultaneously on community assembly (Bernard-Verdier et al. 2012, Price et al. 2013). In this context, the phylogenetic diversity could reinforce and complement the functional approach, especially when a lack of phylogenetic signal is observed in grasslands (Silvertown et al. 2006). In some cases, the phylogeny cannot constitute a good surrogate of functional structure within communities due to the weak relationship between species relatedness and the strength of competition (Cahill et al. 2008, Bernard-Verdier et al. 2013). As an example, in this study, the Brometalia seems more phylogenetically dispersed, while a multi-trait approach reveals a more under-dispersed pattern. Thus, in agreement with other recent studies (Kluge \& Kessler 2011, Cianciaruso et al. 2012), our analysis suggests that the phylogeny might not be the better surrogate of the functional space. However, this conclusion may depend on the chosen traits, and needs to consider the relative importance of biotic and abiotic filters shaping a community. For instance, competition may sometimes eliminate phylogenetically distant species despite the traits are phylogenetically conserved (Mayfield \& Levine 2010).

\section{Potential management-induced effects}

Given the theoretical relations between functional traits and disturbances (Mouillot et al. 2013), we assumed that the functional metrics may indicate potential managementinduced disturbance differences among phytosociological vegetation units. Besides, these management regimes were considered in the ecological characterization of syntaxa (Ferrez 2007).

In this context, the observation of shrubs and tree saplings in relevés of the Brometalia suggests an extensive grazing with no mowing, while a potential trampling disturbance could explain the larger proportion of rosette and semi-rosette species and lower LDMC (Bakker 1998).

In contrast, in the other orders, taller communities with higher SLA values rather suggest nutrient inputs promoting the development of fast-growing annual species, especially competitive for light resource. Thus, a high canopy height allows the overtopping of the surrounding vegetation, a process associated with shade avoidance strategy. On the contrary, a high SLA is frequently considered as a complementary strategy of shade tolerance, even though both may be observed in the same community (Gubsch et al. 2011). The higher values of these two traits, combined with the existence of heavier seeds, thus potentially suggests a mowing management of the Arrhenatheretalia order, as considered in the syntaxa description (Ferrez 2007). On the contrary, the Trifolio-Phleetalia may be mainly grazed (Ferrez 2007). Indeed, the well-known fine-scale spatial heterogeneity due to cattle behavior leads gaps in canopy, making the competition for light lower in grazed than mowed grasslands, and thus promoting seedling recruitment from lighter seeds, including several annual species (Eriksson \& Eriksson 1997, Jacquemyn et al. 2003, Kahmen \& Poschlod 2008).

\section{Limitations and prospects}

We are cognizant that several limitations require further studies to confirm the results. As an example, the use of meantrait values retrieved from databases, although often close to the field data values (Kazakou et al. 2013), seems less reliable than field measurements when studying fine-scale processes (Cordlandwehr et al. 2013). Moreover, the knowledge of direct information on land-use history, landscape characteristics as well as a detailed characterization of farming practices, especially when mixed management was applied (i.e. mowing and grazing during the same season) seems crucial to better understand the community assembly.

Further analyses using data about management practices applied to grasslands in the study area will be carried out, especially to address the question of the impact of such mixed management regime on biodiversity.

\section{SUPPLEMENTARY DATA}

Supplementary data are available in pdf at Plant Ecology and Evolution, Supplementary Data Site (http://www.ingentaconnect.com/content/botbel/plecevo.supp-data), and consists of the following: (1) taxonomic composition of the Angiosperm phylogenetic tree composed of 54 families, 207 
genera and 426 species; (2) Moran's I statistic for each of sixteen diversity metrics and Spearman rank correlation coefficients among each diversity metric and the altitude per site split by phytosociological orders; (3) percentage of the different categories of leaves distribution along the stem, and percentage of the different categories of the most represented CGO weighted by the relative abundance of species in each phytosociological order; and (4) Spearman rank correlations among diversity metrics.

\section{ACKNOWLEDGEMENTS}

We thank Yorick Ferrez and the CBNFC (Conservatoire Botanique National de Franche-Comté) for the provision of phytosociological relevés. This research was supported by the Conseil Régional of Franche-Comté and the Comité Interprofessionnel du Gruyère de Comté. We are grateful to the two anonymous reviewers who helped us improving the manuscript.

\section{REFERENCES}

APG (Angiosperm Phylogeny Group) (2009) An update of the Angiosperm Phylogeny Group classification for the orders and families of flowering plants: APG III. Botanical Journal of the Linnean Society 161: 105-121. http://dx.doi.org/10.1111/ j.1095-8339.2009.00996.x

Bakker J.P. (1998) The impact of grazing on plant communities. In: Wallis deVries M.F., Bakker J.P., van Wieren S.E. (eds) Grazing and conservation management: 137-184. Dordrecht, Kluwer Academic Publisher.

Bell C.D., Soltis D.E., Soltis P.A. (2005) The age of the angiosperms: a molecular timescale without a clock. Evolution 59: 1245-1258. http://dx.doi.org/10.1111/j.0014-3820.2005. tb01775.x

Benson D.A., Karsch-Mizrachi I., Lipman D.J., Ostell J., Wheeler D.L. (2006) GenBank. Nucleic Acids Research 34: D16-D20. http://dx.doi.org/10.1093/nar/gkj157

Bernard-Verdier M., Navas M-L., Vellend M., Violle C., Fayolle A., Garnier E. (2012) Community assembly along a soil depth gradient: contrasting patterns of plant trait convergence and divergence in a Mediterranean rangeland. Journal of Ecology. 100: 1422-1433. http://dx.doi.org/10.1111/1365-2745.12003

Bernard-Verdier M., Flores O., Navas M-L., Garnier E. (2013) Partitioning phylogenetic and functional diversity into alpha and beta components along an environmental gradient in a Mediterranean rangeland. Journal of Vegetation Science. 24: 877-889. http://dx.doi.org/10.1111/jvs.12048

Bernhardt-Römermann M., Römermann C., Sperlich S., Schmidt W. (2011) Explaining grassland biomass the contribution of climate, species and functional diversity depends on fertilization and mowing frequency. Journal of Applied Ecology 48: 10881097. http://dx.doi.org/10.1111/j.1365-2664.2011.01968.x

Blomberg S.P., Garland T., Ives A.R. (2003) Testing for phylogenetic signal in comparative data: behavioral traits are more labile. Evolution 57: 717-745. http://dx.doi. org $/ 10.1111 / j .0014-3820.2003 . t 600285 . x$

Borcard D., Gillet F., Legendre P. (2011) Numerical Ecology with R. New York, Springer.

Braun-Blanquet J. (1964) Pflanzensoziologie - Grundzüge der Vegetationskunde. $3^{\text {rd }}$ Ed. Wien, Springer.
Cahill J.F., Kembel S.W., Lamb E.G., Keddy P.A. (2008) Does phylogenetic relatedness influence the strength of competition among vascular plants? Perspectives in Plant Ecology, Evolution and Systematics. 10: 41-50. http://dx.doi.org/10.1016/j. ppees.2007.10.001

Chessel D., Dufour A.S., Dray S. (2013) ade4: Analysis of Ecological Data: Exploratory and Euclidean methods in Environmental sciences [online]. Available from http://cran.r-project.org/web/ packages/ade4/index.html [accessed 4 Mar. 2014].

Cianciaruso M.V., Silva I.A., Batalha M.A., Gaston K.J., Owen L.P. (2012) The influence of fire on phylogenetic and functional structure of woody savannas: Moving from species to individuals. Perspectives in Plant Ecology, Evolution and Systematics 14: 205-216. http://dx.doi.org/10.1016/j.ppees.2011.11.004

Cordlandwehr V., Meredith R.L., Ozinga W.A., Bekker R.M., van Groenendael J.M., Bakker J. (2013) Do plant traits retrieved from a database accurately predict on-site measurements? Journal of Ecology 101: 662-670. http://dx.doi.org/10.1111/[3652745.12091

Davies T.J., Wolkovich E.M., Kraft N.J.B., Salamin N., Allen J.M., Ault T.R., Betancourt J.L., Bolmgren K., Cleland E.E., Cook B.I., Crimmins T.M., Mazer S.J., McCabe G.J., Pau S., Regetz J., Schwartz M.D., Travers S.E. (2013) Phylogenetic conservatism in plant phenology. Journal of Ecology 101: 1520-1530. http://dx.doi.org/10.1111/1365-2745.12154

de Bello F., Lavergne S., Meynard C., Lepš J., Thuiller W. (2010) The partitioning of diversity: Showing Theseus a way out of the labyrinth. Journal of Vegetation Science 21: 992-1000. http:// dx.doi.org/10.1111/j.1654-1103.2010.01195.x

Dengler J., Jansen F., Glöckner F., Peet R.K., De Caceres M., Chytry M., Ewald J., Oldeland J., Lopez-Gonzales G., Finckh M., Mucina L., Rodwell J.S., Schaminée J.H.J., Spencer N. (2011) The Global Index of Vegetation-Plot Database (GIVD): A new resource for vegetation science. Journal of Vegetation Science 22: 582-597. http://dx.doi.org/10.1111/j.1654-1103.2011.01265.x

Devictor,V., Mouillot D., Meynard C., Jiguet F., Thuiller W., Mouquet N. (2010) Spatial mismatch and congruence between taxonomic, phylogenetic and functional diversity: The need for integrative conservation strategies in a changing world. Ecology Letters 13: 1030-1040. http://dx.doi.org/10.1111/j. $\overline{1461-}$ $0248.2010 .01493 . \mathrm{x}$

Drummond A.J., Ho S.Y.W., Phillips M.J., Rambaut A. (2006) Relaxed phylogenetics and dating with confidence. PLoS Biology 4: e88. http://dx.doi.org/10.1371/journal.pbio.0040088

Drummond A.J., Rambaut A. (2007) BEAST: Bayesian evolutionary analysis by sampling trees. BMC Evolutionary Biology 7: 214. http://dx.doi.org/10.1186/1471-2148-7-214

Eriksson Å., Eriksson O. (1997) Seedling recruitment in seminatural pastures: the effects of disturbances, seed size, phenology and the seed bank. Nordic Journal of Botany 17: 469-482. http://dx.doi.org/10.1111/j.1756-1051.1997.tb00344.x

Ferrez Y. (2007) Contribution à l'étude phytosociologique des prairies mésophiles de Franche-Comté. Les Nouvelles Archives de la Flore Jurassienne 5: 59-151.

Ferrez Y., Bailly G., Beaufils T., Collaud R., Caillet M., Fernez T., Gillet F., Guyonneau J., Hennequin C., Royer J.-M., Schmitt A., Vergon-Trivaudey M.-J., Vadam J.-C., Vuillemenot M. (2011) Synopsis des groupements végétaux de Franche-Comté [online]. Société botanique de Franche-Comté, Conservatoire botanique national de Franche-Comté, Besançon, coll. Les Nouvelles Archives de la Flore jurassienne et du nord-est de la France, $\mathrm{n}^{\circ}$ spécial 1. Available from http://conservatoirebotanique-fc.org/index.php?option=com_docman\&task=doc download\&gid=261\&ltemid=189 [accessed 4 Mar. 2014]. 
Garnier E., Cortez J., Billès G., Navas M-L., Roumet C., Debussche M., Laurent G., Blanchard A., Aubry D., Bellmann A., Neill C., Toussaint J-P. (2004) Plant functional markers capture ecosystem properties during secondary succession. Ecology 85: 26302637. http://dx.doi.org/10.1890/03-0799

Gaujour E., Amiaud B., Mignolet C., Plantureux S. (2012) Factors and processes affecting plant biodiversity in permanent grasslands: A review. Agronomy for Sustainable Development 32: 133-160. http://dx.doi.org/10.1007/s13593-011-0015-3

Gillet F. (2010) Guide d'utilisation de Phytobase 8, base de données phytosociologiques [online]. Université de Franche-Comté, Laboratoire Chrono-environnement, Besançon. Available from http://www.tela-botanica.org/projets/18/telechargement/17642 [accessed 4 Mar. 2014].

Gillet F., Murisier B., Buttler, A., Gallandat J-.D., Gobat, J-.M. (1999) Influence of tree cover on the diversity of herbaceous communities in subalpine wooded pastures. Applied Vegetation Science 2: 47-54. http://dx.doi.org/10.2307/1478880

Gubsch M., Buchmann N., Schmid B., Schulze E-D., Lipowsky A., Roscher C. (2011) Differential effects of plant diversity on functional variation of grass species. Annals of Botany 107: 157-169. http://dx.doi.org/10.1093/aob/mcq220

Harvey P.H., Pagel M.R. (1991) The comparative method in evolutionary biology. Oxford, Oxford University Press.

Hill M.O. (1973) Diversity and evenness: a unifying notation and its consequence. Ecology 54: 427-432. http://dx.doi. org/10.2307/1934352

Hilu K.W., Borsch T., Müller K., Soltis D.E., Soltis P.S., Savolainen V., Chase M.W., Powell M.P., Alice L.A., Evans R., Sauquet H., Neinhuis C., Slotta T.A.B., Rohwer J.G., Campbell S.C., Chatrou L.W. (2003) Angiosperm phylogeny based on matK sequence information. American Journal of Botany 90: 17581776. http://dx.doi.org/10.3732/ajb.90.12.1758

Holm S. (1979) A simple sequentially rejective multiple test procedure. Scandinavian Journal of Statistics 6: 65-70.

Jacquemyn H., Brys R., Hermy M. (2003) Short-term effects of different management regimes on the response of calcareous grassland vegetation to increased nitrogen. Biological Conservation 111: 137-147. http://dx.doi.org/10.1016/S00063207(02)00256-2

Jäger E.J. (2000) Rothmaler Exkursionsflora von Deutschland. Gefäßpflanzen: Atlasband. Berlin, Gustav Fischer Verlag.

Jost L. (2007) Partitioning diversity into independent alpha and beta components. Ecology 88: 2427-2439. http://dx.doi. org/10.1890/06-1736.1

Julve P. (1993) Synopsis phytosociologique de la France (communautés de plantes vasculaires). Lejeunia 140: 1-160.

Julve P. (2013) Baseflor : Index botanique, écologique et chorologique de la flore de France. Baseveg : Répertoire synonymique des groupements végétaux de France [online]. Available from http://perso.wanadoo.fr/philippe.julve/catminat.htm [accessed 4Mar. 2014].

Kahmen S., Poschlod P. (2008) Effects of grassland management on plant functional trait composition. Agriculture, Ecosystems and Environment 128: 137-145. http://dx.doi.org/10.1016/j. agee.2008.05.016

Kazakou E., Violle C., Roumet C., Navas M-L., Vile D., Kattge J., Garnier E. (2013) Are trait-based species rankings consistent across data sets and spatial scales? Journal of Vegetation Science 25: 235-247. http://dx.doi.org/10.1111/jvs.12066

Kembel S.W., Ackerly D.D., Blomberg S.P., Cornwell W.K., Cowan P.D., Helmus M.R., Morlon H., Webb C.O. (2013) picante: $\mathrm{R}$ tools for integrating phylogenies and ecology [online]. Avail- able from http://cran.at.r-project.org/web/packages/picante/index.html [accessed 4 Mar. 2014].

Kleyer M., Bekker R.M., Knevel I.C., Bakker J.P., Thompson K., Sonnenschein M., Poschlod P., van Groenendael J.M., Klimeš L., Klimešova J., Klotz S., Rusch G.M., Hermy M., Adriaens D., Boedeltje G., Bossuyt B., Dannemann A., Endels P., Götzenberger L., Hodgson J.G., Jackel A.K., Kühn I., Kunzmann D., Ozinga W.A., Römermann C., Stadler M., Schlegelmilch J., Steendam H.J., Tackenberg O., Wilmann B., Cornelissen J.H., Eriksson O., Garnier E., Peco B. (2008) The LEDA Traitbase: a database of life history traits of the Northwest European flora. Journal of Ecology 96: 1266-1274. http://dx.doi. org/10.1111/j. 1365-2745.2008.01430.x

Klimešová J., de Bello F. (2009) CLO-PLA: the database of clonal and bud bank traits of Central European flora. Journal of Vegetation Science 20: 511-516. http://dx.doi.org/10.1111/j.16541103.2009.01050.x

Klotz S., Kühn I., Durka W. (2002) Biolflor: Eine Datenbank zu biologisch-ökologischen Merkmalen der Gefäßpflanzen in Deutschland. Schriftenreihe für Vegetationskunde 38.

Kluge J., Kessler M. (2011) Phylogenetic diversity, trait diversity and niches: species assembly of ferns along a tropical elevational gradient. Journal of Biogeography. 38: 394-405. http:// dx.doi.org/10.1111/j.1365-2699.2010.02433.x

Laliberté E., Shipley B. (2013) Measuring functional diversity (FD) from multiple traits, and other tools for functional ecology [online]. Available from http://cran.r-project.org/web/packages/ FD/ [accessed 4 Mar. 2014].

Landolt E., Bäumler B., Erhardt A., Hegg O., Klötzli F., Lämmler W., Nobis M., Rudmann-Maurer K., Schweingruber F.H., Theurillat J.P., Urmi E., Vust M., Wohlgemuth T. (2010) Flora Indicativa: Ecological Indicator Values and Biological Attributes of the Flora of Switzerland and the Alps. Bern, Haupt.

Larkin M.A., Blackshields G., Brown N.P., Chenna R., McGettigan P.A., McWilliam H., Valentin F., Wallace I.M., Wilm A., Lopez R., Thompson J.D., Gibson T.J., Higgins D.G. (2007) Clustal W and Clustal X version 2.0. Bioinformatics 23: 2947-2948. http://dx.doi.org/10.1093/bioinformatics/btm404

Mauchamp L., Gillet F., Mouly A., Badot P-M. (2013) Les prairies : biodiversité et services écosystémiques. Besançon, Presses Universitaires de Franche-Comté - Conseil National des Appellations d'Origine Laitières.

Mayfield M.M., Levine J.M. (2010) Opposing effects of competitive exclusion on the phylogenetic structure of communities. Ecology Letters 13: 1085-1093. http://dx.doi.org/10.1111/ j.1461-0248.2010.01509.x

Mouillot D., Graham N.A.J., Villéger S., Mason N.W.H., Bellwood D.R. (2013) A functional approach reveals community responses to disturbances. Trends in Ecology and Evolution 28: 167 177. http://dx.doi.org/10.1016/j.tree.2012.10.004

Nylander J.A.A. (2004) MrModeltest 20 Program distributed by the author [online]. Evolutionary Biology Centre, Uppsala University, SE. Available from http://www.abc.se/ nylander/ [accessed 4 Mar. 2014].

Oksanen J., Blanchet F.G., Kindt R., Legendre P., Minchin P.R., O'Hara R.B., Simpson G.L., Solymos P., Stevens M.H.H., Wagner H. (2013) vegan: Ordination methods, diversity analysis and other functions for community and vegetation ecologists [online]. Available from http://cran.r-project.org/web/packages/ vegan/index.html [accessed 4 Mar. 2014].

Pakeman R.J. (2013) Intra-specific leaf trait variation: management and fertility matter more than the climate at continental scales. 
Folia Geobotanica. 48: 355-371. http://dx.doi.org/10.1007/ s12224-013-9168-y

Pavoine S., Bonsall M.B. (2011) Measuring biodiversity to explain community assembly: a unified approach. Biological Reviews 86: 792-812. http://dx.doi.org/10.1111/j.1469185X.2010.00171.X

Pellissier L., Fournier B., Guisan A., Vittoz P. (2010) Plant traits co-vary with altitude in grasslands and forests in the European Alps. Plant Ecology 211: 351-365. http://dx.doi.org/10.1007/ s11258-010-9794-X

Price J.N., Gazol A., Tamme R., Hiiesalu I., Pärtel M. (2013) The functional assembly of experimental grasslands in relation to fertility and resource heterogeneity. Functional Ecology 28: 509-519. http://dx.doi.org/10.1111/1365-2435.12186

Rambaut A. (1996) Se-Al, version 1.dl. Sequence alignement program [online]. Available from http://tree.bio.ed.ac.uk/software/ seal/ [accessed 4 Mar. 2014].

R Development Core Team (2013) R: a language and environment for statistical computing [online]. R Foundation for Statistical Computing, Vienna, AT. Available from http://www.r-project. org [accessed 4 Mar. 2014].

Revell L.J. (2013) phytools: Phylogenetic Tools for comparative biology (and other things) [online]. Available from http://cran.rproject.org/web/packages/phytools/index.html [accessed 4 Mar. 2014].

Ricotta C., Moretti M. (2011) CWM and Rao's quadratic diversity: a unified framework for functional ecology. Oecologia 167: 181-188. http://dx.doi.org/10.1007/s00442-011-1965-5

Schaminée J.H.J., Hennekens S., Chytry M., Rodwell J. (2009) Vegetation-plot data and databases in Europe: an overview. Preslia 81: 173-185.

Silvertown J., McConway K., Gowing D., Dodd M., Fay M.F., Joseph J.A., Dolphin K. (2006) Absence of phylogenetic signal in the niche structure of meadow plant communities. Proceedings of the Royal Society of London B 273: 39-44. http://dx.doi. org/10.1098/rspb.2005.3288
Stuart-Smith R.D., Bates A.E., Lefcheck J.F., Duffy J.E., Baker S.C., Thompson R.J., Stuart-Smith J.F., Hill N.A., Kininmonth S.J., Airoldi L., Beccero M.A., Campbell S.J., Dawson T.P., Navarette S.A., Soler G.A., Strain E.M.A., Willis T.J., Edgar G.J. (2013) Integrating abundance and functional traits reveals new global hotspots of fish diversity. Nature 501: 539-542. http://dx.doi.org/10.1038/nature12529

Violle C, Navas M-L., Vile D., Kazakou E., Fortunel C., Hummel I., Garnier E. (2007) Let the concept of trait be functional! Oikos 116: 882-892. http://dx.doi.org/10.1111/j.2007.00301299.15559.x

Westhoff V., van der Maarel E. (1978) The Braun-Blanquet approach. In: Whittaker R.H. (ed.) Classification of plant communities: 287-399. The Hague, W. Junk.

Wilsey B.J., Polley H.W. (2003) Effects of seed additions and grazing history on diversity and aboveground productivity of sub-humid grasslands. Ecology 84: 920-932. http://dx.doi.

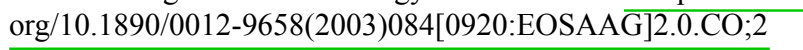

Wilson J.B., Peet R.K., Dengler J., Pärtel M. (2012) Plant species richness: the world records. Journal of Vegetation Science 23: 796-802. http://dx.doi.org/10.1111/j.1654-1103.2012.01400.x

Yang Z. (1994) Maximum likelihood phylogenetic estimation from DNA sequences with variable rates over sites: approximate methods. Journal of Molecular Evolution 39: 306-314. http:// dx.doi.org/10.1007/BF00160154

Zhang J., Pei N., Mi X. (2012) phylotools: Phylogenetic tools for Eco-phylogenetics [online]. Available from http://cran.r-project.org/web/packages/phylotools/index.html [accessed 4 Mar. 2014].

Manuscript received 10 May 2013; accepted in revised version 14 Apr. 2014.

Communicating Editor: Elmar Robbrecht. 